\title{
Preservice Turkish language teachers' attitudes toward Anatolian dialects
}

İzzet Şeref

Department of Turkish Education, Tokat Gaziosmanpaşa University, Turkey

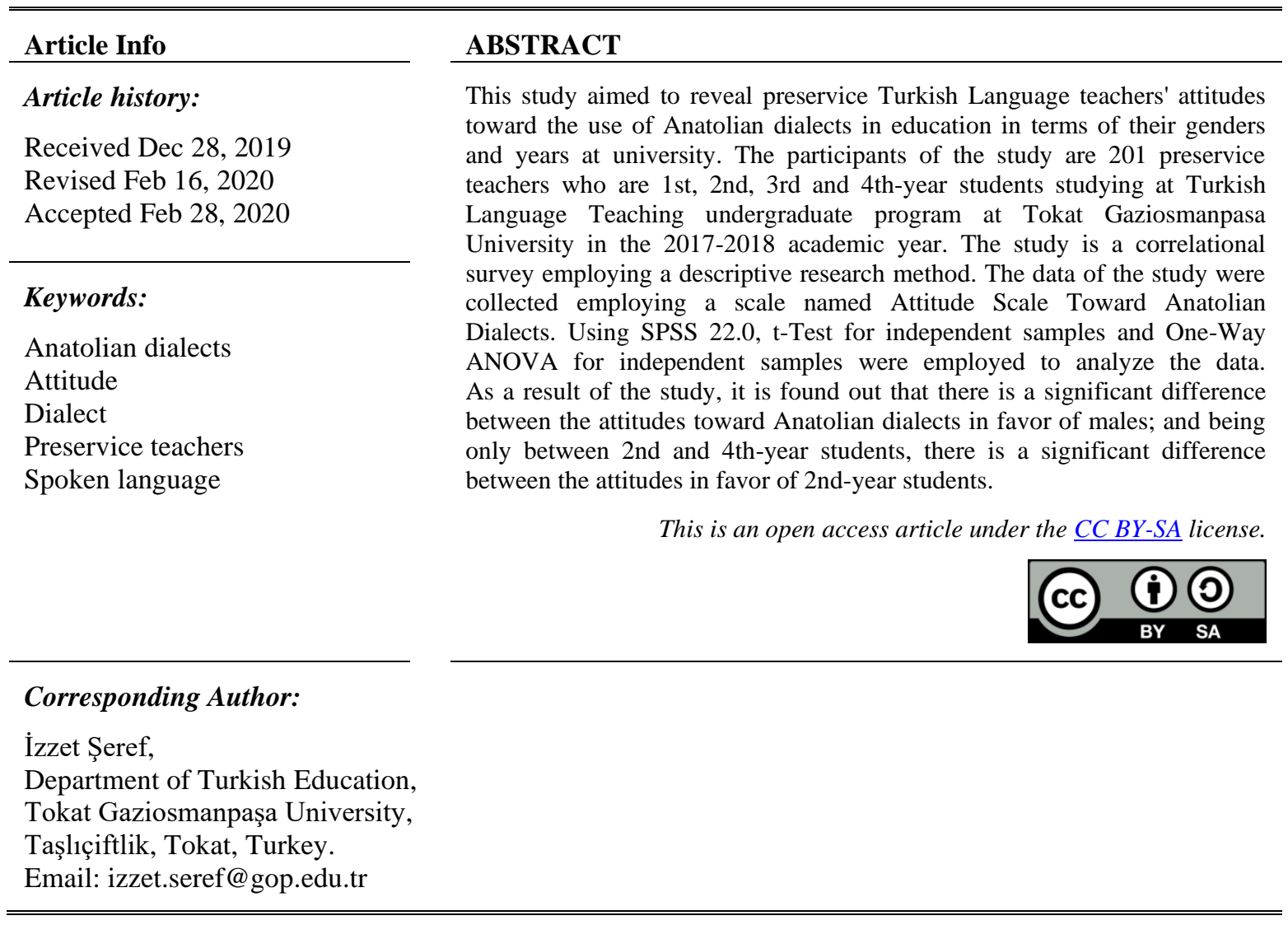

\section{INTRODUCTION}

There are some points where the spoken language. that is to say, oral language, differs from the written language. When compared to the written language, which is also called standard language; oral language includes types of speech which may vary according to regions, social groups and even individuals. The forms of spoken language, which are based on the differences in sounds between regions, are called dialect. In smaller places where a language or dialect is spoken, spoken forms that are more or less separated from the written language constitute the features of the dialect. The origins of the dialects are based on an ancestor language. Dialects and accents have emerged as a result of the development of the ancestor languages in terms of different sounds, forms, meanings and syntax [1]. The term "dialect", which is a small unit in the standard spoken language, is defined as the language spoken in a certain region of a written language and the language that has particular pronunciation features due to geographical differences [2]. According to Aksan, dialect is the name given to small branches that exist in an accent, which are based on discourse differences. and the speeches of various regions and cities in a country that are separate from each other in terms of word articulation" [3].

The use of dialects is considered a speech defect in the speech literature. Gurlek and Aksu, states that the use of local discourse, that is dialects, is a speech defect and that language speakers should correct this through correctly written books and correctly voiced films [4], etc. Similarly, Gogus [5] suggests that minimizing the use of dialects is very important in helping students acquire speaking skill. Aydin [6] 
mentions the effect of the use of dialects on writing skills in mother tongue teaching and argues that the Spelling Book, not the features of the dialects, should be consulted to correct spelling mistakes. Alperen [7] states that the Turkish Language teachers have a great role in the use of standard language and that Turkish teachers who do not use Turkish correctly or who use dialects in educational environments cannot be successful in mother-tongue teaching.

Eryilmaz [8], who discusses the views on dialects in the speech literature, states that there are views arguing that dialects are obstacles in the way of the written language to develop and become widespread, along with the ones arguing that they are important resources for a more comprehensive and accurate understanding of Turkish and should not be denied, even they should be protected as a part of the language.

In the studies conducted on dialects in Turkish spoken in Turkey, it is emphasized that Anatolian dialects are the richness of Turkish. In other words, dialects are the main sources that feed Turkish. However, the goal of language teaching is to enable students to express themselves well following the vocal characteristics of the standard language. For this reason, it is the standard language that should be used in language teaching and students should learn the basic language skills through qualified examples of the standard language. In other words, it is the basic responsibility of teaching to help the students learn the language features such as liaison, emphasis. and intonation following the principles of the standard language [9]. In this context, Turkish language teachers stand out as the main determinant in the process of mother-tongue teaching. Therefore, it is crucial to see the level of future Turkish language teachers' perceptions of Anatolian dialects and to determine their attitudes toward these dialects.

When the literature is examined, it is seen that there have been many studies on speech problems in the field of Turkish education in recent years. These studies focus on the detection of speech problems and the development of speaking skill, It is seen that these studies are usually grouped under the titles of speech errors, speech faults, speech defects and speech deficiencies [10-14]. However, when the literature is examined, it is observed that the number of studies investigating the attitudes toward the dialects and the stakeholders' views (teachers. students. etc.) on this issue is limited. The studies conducted show that the attitudes toward Anatolian dialects have not been investigated sufficiently. However, attitudes are the cornerstone of motivation that affects the success in the first degree [15]. In other words, studies to determine attitudes in any field will be of decisive importance in planning the teaching process. Therefore, this study is to contribute to the literature by revealing preservice Turkish language teachers' attitudes toward the use of Anatolian dialects in different areas. To this end, the question we seek to answer is "Is there a statistically significant relationship between preservice Turkish language teachers' attitudes toward Anatolian dialects and their genders and years at university?

\section{RESEARCH METHOD}

\subsection{The model of the study}

This study was conducted in correlational survey model. which is one of the quantitative research designs. This model is a research model that aims to determine the existence and/or degree of covariance between two and more variables [16]. Correlational survey model was chosen in the study to reveal the relationship between Anatolian dialects and some variables (gender. years at university. mother's level of education. mother's job. father's level of education. father's job. level of income. communicating with elders. communicating in a different city).

\subsection{Sample}

The sample of the study is 201 preservice teachers who are 1st. 2nd. 3rd and 4th-year students studying at Turkish Language Teaching undergraduate program at Tokat Gaziosmanpasa University in the 2017-2018 academic year. Descriptive information of the preservice teachers who participated in the study is given in Table 1.

Table 1. Preservice teachers' descriptive characteristics

\begin{tabular}{cccc}
\hline Demographic Variables & Sub-Categories & $\mathrm{f}$ & $\%$ \\
\hline \multirow{2}{*}{ Gender } & Female & 130 & 64.7 \\
& Male & 71 & 35.3 \\
& 1 & 54 & 26.9 \\
Years at University & 2 & 36 & 17.9 \\
& 3 & 62 & 30.8 \\
Total & 4 & 49 & 24.4 \\
\hline
\end{tabular}




\subsection{Data collection tool}

The data of the study were collected employing a scale named "Attitude Scale Toward Anatolian Dialects" developed by Pehlivan (2012b) [17]. The scale, developed as a Likert-type five-point scale, has 22 items, 11 of which are positive (2-4-6-8-10-12-14-16-19-21-22) and 11 of which are negative (1-3-5-7-9-1113-15-17-18-20). Pehlivan (2012b) states that the Cronbach alpha reliability coefficient of the scale is 0.88 [17]. As a result of the reliability study repeated by the researcher. the Cronbach's alpha reliability coefficient of the scale was found to be $0.85(\alpha=0.85)$. These results show that the data collection tool is useful.

\subsection{Analysis of data}

Statistical analysis of the study was performed using the SPSS 22.0 program. To investigate whether there is a significant relationship between preservice teachers' attitude scores and the variables, t-Test for independent samples and One-Way ANOVA for independent samples were employed. Before this. normality tests were used. When the researcher decided that the data are distributed normally according to the normality values (Shapiro-Wilk test; kurtosis and skewness coefficients with mode, median and arithmetic mean; Stem and Leaf Diagram; Histogram; Detrended Normal Q-Q Plot; Normal Q-Q Plot P-P Plot. Boxplot), parametric tests were performed.

\section{RESULTS AND DISCUSSION}

In this section. preservice teachers' attitudes toward the Anatolian dialects are examined according to their genders and years at university and the data obtained are presented in the Table 2.

According to Table 2 preservice teachers' attitudes toward the Anatolian dialects according to the gender variable. According to this, there is a significant difference in favor of males in the item "Using the regional dialect in education increases students' cultural knowledge about the region". In other words, male preservice teachers believe that using the regional dialects increases their cultural knowledge about the region more than females do. In the item "To increase the success in teaching. the dialect of the child's region should be used", which is in line with the second item, males' attitudes are higher. In the item "Learning the Anatolian dialects at school negatively affects the status of Turkish", which does not match the two previously mentioned items, it is seen that the average of males is significantly higher. This item suggests that dialects should not be used in education. When this contradiction is taken into consideration, it can be said that preservice teachers do not have a careful consciousness about the use of dialects. In the ninth item. which is "People with regional dialect are not more sincere", it is seen that females have higher attitudes. Items 2, 6, 7 and 12, which is "Appreciating the value of regional dialect increases the student's self-confidence", can be evaluated together due to the educational aspect. In items 13, 22 and 19 , it is seen that the average of males is higher. When these items are evaluated holistically, it can be said that males have more positive attitudes toward the use of dialects in education than females, but they think that their dialect should be used first. As a general evaluation, males' overall score in the scale is higher than the females' and this result can be statistically significant and supported by the factors in the scale.

According to Table 3 shows preservice teachers' attitudes toward dialects in line with the factors in the scale according to the gender variable. When the significance level is taken into consideration, it is seen that there is a significant difference in favor of males in factors 1,3 and 4 of the scale and that preservice teachers' average attitude scores are very close to each other in factor 2 . The study also examines preservice teachers' attitudes toward dialects according to their years at university.

According to Table 4 shows the preservice teachers' attitudes toward dialects according to their years at university. According to this, the average of the first-year preservice teachers is 3.07, second-year teachers' is 3.19, third-year teachers' is 3.05 and the fourth-year teachers' is 2.97 . The highest average score belongs to the second-year preservice teachers $(\bar{X}=3.19)$. Whether there is a significant difference between these data is shown in Table 5.

According to Table 5 there is no significant difference between the preservice teachers' attitudes toward the dialect. Although the average score of second-year preservice teachers is higher than the others. this result is not statistically significant. However, when the data are analyzed in the context of the factors. being between second-year $(\bar{X}=3.20)$ and fourth-year $(\bar{X}=2.70)$ preservice teachers, there is a significant difference in favor of second-year preservice teachers $(\mathrm{p}=.001)$. On the other hand, it is necessary to say that preservice teachers' attitudes toward Anatolian dialects are at an average level according to the year variable. 
Table 2. t-test results of preservice Turkish language teachers' attitudes toward Anatolian dialects according to gender variable

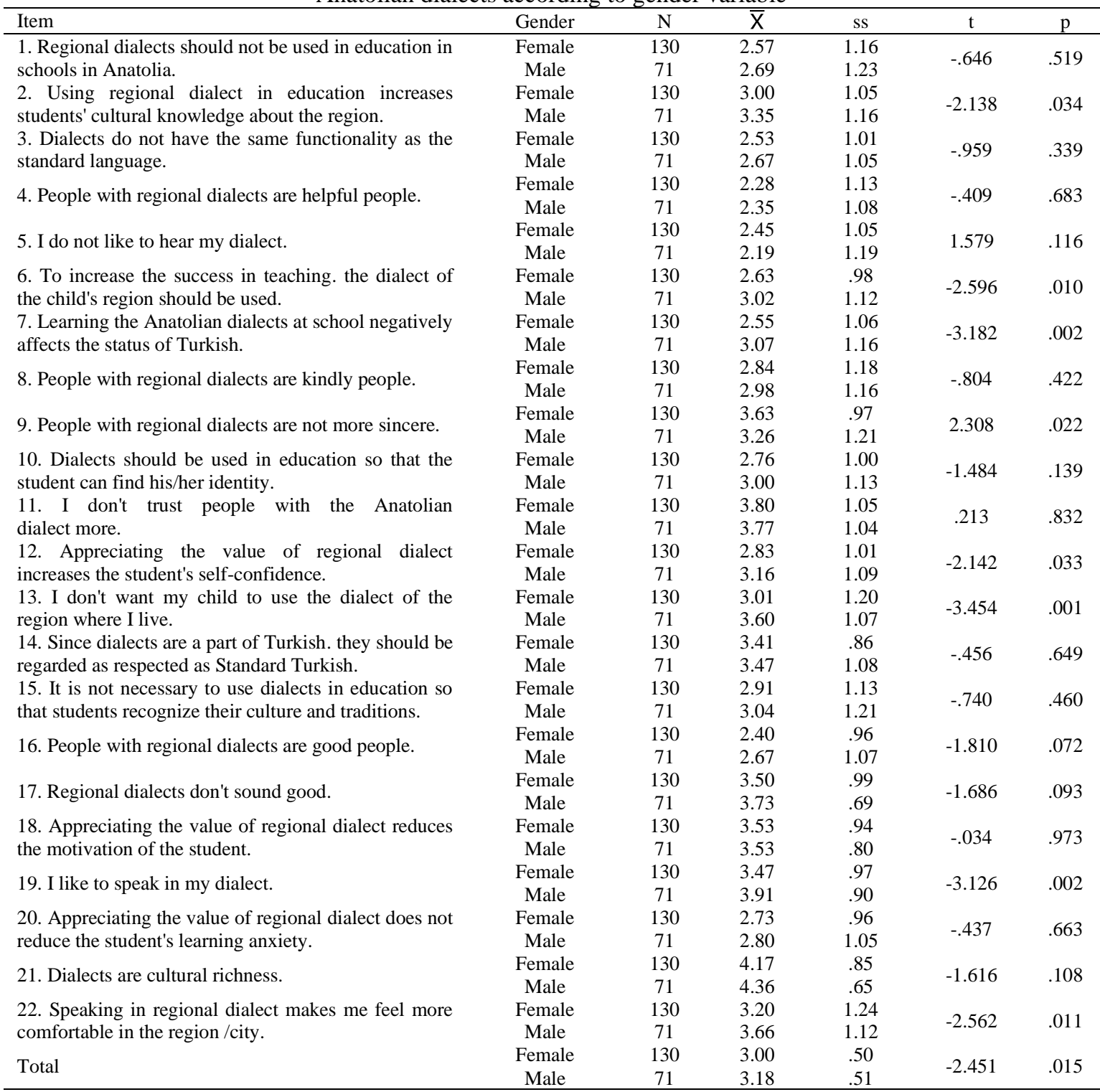

Table 3. t-test results of the scores preservice Turkish language teachers got in the factors in attitude scale toward Anatolian dialects according to gender variable

\begin{tabular}{|c|c|c|c|c|c|c|}
\hline Factors & Gender & $\mathrm{N}$ & $\overline{\mathrm{X}}$ & ss & $\mathrm{t}$ & $\mathrm{p}$ \\
\hline Factor 1. Place and Function of Dialects in Education & Female & 130 & 2.87 & .65 & -1.985 & .049 \\
\hline Factor 2. Attitudes Toward Dialect Users & Female & 130 & 2.99 & .71 & -.142 & .887 \\
\hline \multirow{2}{*}{ Factor 3. Emotional Value Toward The Use of Dialects } & Female & 130 & 3.30 & .54 & \multirow{2}{*}{-3.511} & \multirow{2}{*}{.001} \\
\hline & Male & 71 & 3.57 & .49 & & \\
\hline Factor 4. The Status of Dialects & Female & 130 & 2.83 & .68 & -2.297 & .023 \\
\hline Total & Male & 71 & 3.18 & .51 & -2.451 & .015 \\
\hline
\end{tabular}


Table 4. Findings describing preservice Turkish language teachers' attitudes toward Anatolian dialects according to the year variable

\begin{tabular}{cccccc}
\hline \multirow{2}{*}{ Year } & $\mathrm{N}$ & $\overline{\mathrm{X}}$ & ss & \multicolumn{2}{c}{ 95\% Confidence Interval } \\
& & & & Lower limit & Upper limit \\
\hline 1 & 54 & 3.07 & .56 & 2.92 & 3.23 \\
2 & 36 & 3.19 & .49 & 3.02 & 3.36 \\
3 & 62 & 3.05 & .41 & 2.95 & 3.16 \\
4 & 49 & 2.97 & .57 & 2.81 & 3.13 \\
Total & 201 & 3.06 & .51 & 2.99 & 3.13 \\
\hline
\end{tabular}

Table 5. ANOVA results of preservice Turkish language teachers' attitudes toward Anatolian dialects according to the year variable

\begin{tabular}{cccccc}
\hline Sources of Variance & Sum Squares & Sd & Mean Squares & F & p \\
\hline Intergroup & .997 & 3 & .332 & & \\
Within-group & 51.550 & 197 & .262 & 1.270 & .286 \\
(error) & 52.547 & 200 & & & \\
Total & & & & & \\
\hline
\end{tabular}

Spelling rules are the rules established to ensure the standard of speaking and writing among the users of a language and to prevent possible mistakes and errors in the language. However, it is an undeniable fact that spelling rules ignore the dialects. see the dialects. which form the sources of the standard language. as a distorted form of the standard language. try to assimilate the dialects into the standard language and struggle against the dialects that they cannot assimilate into the standard language [18]. In other words. all kinds of speaking forms except for the standard language such as idiolects. dialects or sociolects are considered a communication defect in the society. even though those speaking forms offer important clues to linguists with their diversity of sound-form and meaning [2]. This issue is discussed in educational environments as well. On one hand. the use of dialects in education is seen as a speech defect. on the other hand. there are discussions on how to avoid the use of dialects and how to improve ways or methods to overcome the use of dialects. Regarding this issue. Eryilmaz. suggests that Turkish language teachers could use the following in the case of the use of dialects: 1. determining the use of local dialect. 2. determining the equivalence of local dialect in written language. 3. checking whether the corrected use of dialect continues or not [8]. In a more general sense. Demirel. states that children who speak in local dialects should not be corrected especially with his friends around in case it may cause affective problems [19]. He also states that reading a lot to the child with a local dialect. making him/her read aloud. recording his/her sound and then playing it could be beneficial to correct the use of dialects.

When the studies in the literature are evaluated holistically. it is understood that the use of dialect is a defect and this use should be corrected in teaching the Turkish language as a mother tongue. However, while the use of dialects in education can be encountered. teachers should consider student anxiety in teaching the rules of the standard language and develop strategies in this direction. If this situation is ignored. students' anxiety about basic language skills is inevitably higher than it should be. The studies confirm this idea [20-21]. Therefore. it is important to keep the anxiety at an optimum level so that students develop terminal behaviors. Focusing on how students express themselves. rather than what they are saying or how they can improve and plan their content of speech. can hinder the success in education. For this reason, the efficiency of the learning process should not be ignored while correctly teaching the Turkish language.

International studies focusing on the use of dialect. accent and local language in education respond to how the process should be approached. Unlike the ones in Turkey. these studies focus on minority language and the use of accents as well. Yiakoumetti. in his study based on multilingualism in education. concludes that the use of dialectical diversity (dialect. local dialect) in the classroom provides many advantages [22]. Other studies in which similar discussions have been made can be listed as follows: [23-30]. In these studies. researchers point out that the use of dialects and local languages in education can be allowed and this may have positive results.

According to the literature, it is an important area of research to understand what preservice Turkish language teachers think about the use of dialects in education and how they approach this issue in terms of efficiency of the teaching process. In this study. which aims to determine preservice Turkish language teachers' attitudes toward Anatolian dialects. it is found out that preservice teachers' attitudes are at an average level and there is a significant difference in favor of males while the year variable makes no difference on attitudes. In a study by Cross, DeVaney and Jones, preservice teachers' attitudes toward dialects do not differ according to their gender and academic achievement [31]. Regarding this result. Demirci, found out that the attitudes toward Anatolian dialects do not differ according to gender [32]. 


\section{CONCLUSION}

In a holistic evaluation. the results of this study show that preservice teachers' attitudes toward the use of dialects are not explicit. More specifically. the item average of the first factor. which is Place and Function of Dialects in Education. can be interpreted as preservice teachers have not developed a positive or negative attitude about the place of dialects in education. In other words, they did not give a clear idea about the use of dialects in educational environments.

This study is limited to preservice Turkish language teachers' views studying at Tokat Gaziosmanpaşa University. So, it should be stated that there is a need for studies that will be conducted with data from different samples to make more general evaluations about preservice teachers' attitudes toward Anatolian dialects.

\section{REFERENCES}

[1] Tekin. F., ve Cantürk. S., “Giresun ve Yöresi Ağızlarından Derleme Sözlüğü’ne Katkılar.” Diyalektolog-A Araştırmaları Dergisi, vol. 9, pp. 22-46, 2014.

[2] Karaağaç. G., Dil Bilimi Terimleri Sözlü̆̆̈̈, Ankara: Türk Dil Kurumu Yayınları, 2013.

[3] Aksan. D., Türkiye Türkçesinin Dünü. Bugünü, Yarını, Ankara: Bilgi Yayınevi, 2005.

[4] Gürlek. M. ve Aksu. E., "Konuşma hataları,” Abdullah Şahin (Ed.), Konuşma Eğitimi-Yöntemler, Etkinlikler içinde, Ankara: Pegem Akademi Yayınları, 2015.

[5] Göğüş, B. Illköğretim Okullarında Türkçe Öğretimi ve Sorunları, Ankara: TED Yayınları, 1993.

[6] Aydın. İ., "Türkçe Öğretiminde Yazılı Anlatım Çalışmalarındaki Sorunlar Üzerine Bir İnceleme," KMÜ Sosyal ve Ekonomik Araștırmalar Dergisi, vol. 16, pp. 166-170, 2014.

[7] Alperen. N., Türkçe (Güzel Konuşma. Okuma ve Yazma) Öğretim Rehberi, İstanbul: MEB Basımevi, 1991.

[8] Eryılmaz, R. Çameli Ilçesi Ağzı ve Çameli Ortaokullarında Ĕ̆itim Gören Öğrencilerin Yerel Ağız Özelliklerinin Türkçe Eğitimine Etkisi (Yayımlanmamış Yüksek Lisans Tezi), Denizli: Pamukkale Üniversitesi Eğitim Bilimleri Enstitüsü, 2015.

[9] Sever. S., Aslan. C. ve Kaya. Z., Etkinliklerle Türkçe Öğretimi, İzmir: Tudem Yayınları, 2011.

[10] Büyükikiz. K. K. \& Hasırcı. S., "Türkçe Öğrenen Yabancı Öğrencilerin Konuşma Becerisine Yönelik Görüşleri," Gaziantep University Journal of Social Sciences, vol. 12, no. 4. pp. 897-912. 2013.

[11] Uçgun. D., "Konuşma Eğitimini Etkileyen Faktörler," Niğde Üniversitesi Sosyal Bilimler Enstitüsü Dergisi, vol. 22, no. 1, pp. 59-67, 2007

[12] Topçuoğlu. F., ve Degeç. H., "Öğretmen Görüşlerine Göre Konuşma Eğitiminde Karşılaşılan Sorunlar," JASSS. vol. 5, no. 7, pp. 735-750, 2012.

[13] Erdem. İ., "Konuşma Eğitimi Esnasında Karşılaşılan Konuşma Bozuklukları ve Bunları Düzeltme Yolları,” Journal of Social Sciences, vol. 6, no. 11, pp. 415-452, 2013.

[14] Akkaya. A., "The opinions of teacher candidates about speech problems," Mustafa Kemal University Journal of Social Sciences Institute, vol. 9, no. 20, pp. 405-420, 2012.

[15] Özbay. M., Bağcı. H., ve Uyar. Y., "Türkçe Öğretmeni Adaylarının Okuma Alışkanlığına Yönelik Tutumlarının Çeşitli Değişkenlere Göre Değerlendirilmesi,” İn̈̈n̈̈ Üniversitesi Eğitim Fakültesi Dergisi, vol. 9, no. 15, pp. 117-136. 2008.

[16] Karasar. N., Bilimsel Araştırma Yöntemi, Ankara: Nobel Akademi Yayıncılık, 2014.

[17] Pehlivan. A., "Öğretmen Adaylarının Anadolu Ağızlarına Yönelik Tutum Ölçeğinin Geçerlik ve Güvenirlik Çalışması,” Bilig, vol. 63, pp. 135, 2012.

[18] Aly1lmaz. S. and Alyılmaz. C., "The importance of dialectology studies in regards to Turkish teaching.". Turkish World Journal Of Language And Literature, vol. 45, pp. 7-38, 2018.

[19] Demirel. Ö., İlköğretim Okullarında Türkçe Öğretimi, İstanbul: Millı̂ Eğitim Bakanlığı Yayınları, 1999.

[20] İşcan. A. \& ve Karagöz. B., "Türkçe Öğretmeni Adaylarının Konuşma Kaygılarının Incelenmesi (Gaziosmanpaşa Üniversitesi örneği)," Journal of Kirsehir Education Faculty, vol. 17, no. 3, pp. 193-206, 2016.

[21] Ürün Karahan. B., "Türkçe Öğretmeni Adaylarının Yazma Kaygıları ile Yazma Alışkanlıkları Arasındaki İlişki," Journal of the Human \& Social Science Researches, vol. 6 no. 5, pp. 3065-3075, 2017.

[22] Yiakoumetti. A., "Choice of classroom language in Bidialectal communities: To include or to exclude the dialect?," Cambridge Journal of Education, vol. 37, no. 1, pp. 51-66, 2007.

[23] Reinecke. J. E., Language and dialect in Hawaii. A sociolinguistic history to 1935, Hanolulu: University of Hawaii. 1969.

[24] Fishma, J. A. "Standard" Versus "Dialect" in Bilingual education: An old problem in a new context," The Modern Language Journal, vol. 61, np. 7, pp. 315-325, 1977.

[25] Adger. C., Wolfram. W., Detwyler. J. \& Harry. B., "Confronting dialect minority issues in special education: Reactive and proactive perspectives", [Online] Available: https://files.eric.ed.gov/fulltext/ED356673.pdf, 1993.

[26] Pavlou. P. \& Papapavlou. A., "Issues of dialect use in education from the Greek Cypriot perspective." International Journal of Applied Linguistics, vol. 14, no. 2, pp. 243-258, 2004.

[27] Siegel. J., "Creoles and Minority dialects in education: An update," Language and Education, vol. 21, no. 1, pp. 66-86, 2007.

[28] Farr. M., Seloni. L. \& Song. J., et al, Ethnolinguistic diversity and education: Language. literacy and culture. Routledge. 2009. 
[29] Brynes. D. and Gary K., "Language attitudes of teachers scale," Educational and Psychological Measurement, vol. 54, no. 1, pp. 227-231, 1994.

[30] Lasagabaster. D. and Angel H., Multilingualism in European Bilingual Context: Language Use and Attitudes, Clevedon: Multilingual Matters, 2006.

[31] Cross. J. B., DeVaney. T. \& Jones. G., "Pre-service teacher attitudes toward differing dialects," Linguistics and Education, vol. 12, no. 2, pp. 211-227, 2001.

[32] Demirci. M., "Gender differences in the perception of Turkish regional dialects," Hanbook of Perceptual Dialectology 2, Eds. Daniel Long and R. Dennis Priston, Amsterdam: John Benjamins, pp. 41-50, 2002. 